\title{
Anaerobic digestion of piggery waste. 3. Influence of temperature
}

\author{
A. F. M. van Velsen, G. Lettinga, D. den Ottelander \\ Agricultural University, Department of Water Purification, De Dreijen 12, Wage- \\ ningen, the Netherlands
}

Accepted: 6 April 1979

Key words: anaerobic digestion, piggery waste, temperature

\section{Summary}

The effects of temperature in the range of 13 to $55^{\circ} \mathrm{C}$ on the digestion of wet piggery manure were investigated in laboratory-scale digesters fed daily at a load of approx. $4 \mathrm{~kg}$ TS (total solids) $\mathrm{m}^{-3} \mathrm{day}^{-1}$. At a digestion temperature of $13^{\circ} \mathrm{C}$ no methane was produced. In the mesophilic temperature range $\left(20-40^{\circ} \mathrm{C}\right)$ the methane production increased with temperature particularly in the range of 20 to $25^{\circ} \mathrm{C}$. In the range of 25 to $40^{\circ} \mathrm{C}$ the increase of the methane production was much less pronounced and hydrolysis of undissolved manure components turned out to be the rate limiting step of the digestion process. Under thermophilic conditions $\left(55^{\circ} \mathrm{C}\right)$ the methane production decreased with approx. $25 \%$ as compared to mesophilic digestion in spite of a somewhat higher degree of hydrolysis. Thermophilic digestion appeared to be more sensitive for high ammonia-nitrogen concentrations than mesophilic digestion which presumably is caused by an increase in the fraction of free ammonia with temperature (at constant $\mathrm{pH}$ and total ammoniacal nitrogen concentration).

From the results it was concluded that digestion under mesophilic conditions is most adequate for piggery waste stabilization. Furthermore the results of the mesophilic experiments indicated that at a load of approx. $4 \mathrm{~kg} \mathrm{TS} \mathrm{m}^{-3}$ day $^{-1}$ the optimum temperature with respect to the net energy recovery is $27-30^{\circ} \mathrm{C}$ when high-grade fuel is required to elevate the temperature and $35-40{ }^{\circ} \mathrm{C}$ when sufficient waste energy is available.

\section{Introduction}

The interest in anaerobic digestion of animal wastes is strongly increasing at present because of environmental concerns such as the abatement of odour nuisance and energy considerations. A very useful fuel, methane gas, is formed upon digestion of organic matter. On the other hand the digestion process consumes energy as well, viz for pumping and mixing and generally also for heating the manure and 
maintaining the digester at the desired temperature. In temporate climates like in Western Europe the greater part of the energy consumption is used for heating purposes (Mills, 1979).

As in these areas evidently the energy requirements of the process chiefly depend on the applied digestion temperature, knowledge of the influence of the temperature on the gas production is indispensable for determining the optimum process temperature with respect to the net energy recovery.

Anaerobic digestion of animal wastes can be conducted at mesophilic temperatures $\left(20-40^{\circ} \mathrm{C}\right)$ and at thermophilic temperatures $\left(40-65^{\circ} \mathrm{C}\right)$. Although thermophilic digestion of manure may have benefits over mesophilic digestion, such as higher rates of digestion, greater conversion of waste organics to gas, faster solidliquid separation and minimization of bacterial and viral pathogens, the mesophilic temperature range should be preferred for animal waste digestion at farm-scale application because of practical reasons.

For digestion in the mesophilic range commonly a temperature of $33-35{ }^{\circ} \mathrm{C}$ is used. This temperature originates from the practice of sewage sludge digestion. However, the optimization of the sewage sludge digestion process has been primarily directed at a maximum stabilization of the sludge - and therefore at a maximum gas production - rather than at a maximum net energy recovery. Our studies were performed to investigate the effects of the temperature on the digestion of wet piggery manure. The main objectives of the study were (1) to assess the digestion temperature at which the maximum gas yield is obtained and (2) to collect sufficient information for optimizing the net energy recovery in the mesophilic temperature range $\left(20-40^{\circ} \mathrm{C}\right)$.

\section{Materials and methods}

\section{Analyses}

The total solids concentration (TS) was determined by drying a $10-\mathrm{ml}$ sample in a $105^{\circ} \mathrm{C}$ stove overnight. Volatile solids (VS) concentration was estimated by determining the weight losses at ignition at $600^{\circ} \mathrm{C}$ for 4 hours. Chemical oxygen demand (COD) analyses were conducted according to Standard Methods (1965). Supernatant COD was determined after centrifugation at $14000 \mathrm{~g}$ for 10 minutes.

Ammonia-nitrogen was determined by distillation at $\mathrm{pH} 7.3$ into a boric acid solution and titration with a standard acid solution. The total nitrogen concentration was determined by the same method preceded by a Kjehldahl type destruction (boiling a $10-\mathrm{ml}$ sample in concentrated sulfuric acid, with Selenium Mixture GR as a catalyser, up to clearness of the sample) and neutralization with concentrated $\mathrm{NaOH}$ before distillation.

The volatile fatty acids (VFA) analyses were performed on a gas chromatograph with a packed glass column $(1 \mathrm{~m} \times 0.4 \mathrm{~cm}$ i.d.) filled with Tween 80 on Chromosorb W-AW 80/100. Column temperature was $115^{\circ} \mathrm{C}$ and the carrier gas, $\mathrm{N}_{2}$, was saturated with formic acid.

Gas analyses were performed with a portable combustile gas meter calibrated for methane. 


\section{Experimental procedure}

The influence of temperature on the digestion of wet piggery manure was investigated in three series of experiments, designated as series A, B and C. In each series three different temperatures were tested. Table 1 shows the temperatures investigated together with the loads applied.

After seeding the digesters with digested piggery manure from a $30^{\circ} \mathrm{C}$ digestion unit the temperatures to be investigated were adjusted immediately. The digesters were fed daily or bidaily (in the weekends) by discharging a calculated amount of the digester contents. Then fresh manure was added at appropriate amounts.

The experiments were continued for a period of at least 25 days after the digestion process had reached a steady state with respect to the gas production and the VFA concentration.

\section{Apparatus}

The experiments of series A and B were performed in three 45-litre insulated steel vessels. The digestion units were heated electrically and the temperature was regulated by means of a thermocouple in the digester contents. Mixing was accomplished by mechanical stirring at approx. $100 \mathrm{rev} / \mathrm{min}$ for $15 \mathrm{~s}$ every $4 \mathrm{~min}$. The stirring device was provided with a propellor fan at the bottom of the digester and a scum-breaker at the liquid-gas interphase. The stirring capacity in the digesters was not sufficient to mix the digester contents completely. The manure feed was added near the bottom of the digester and the effluent was discharged at the upper part. The gas production was determined with a wet gas meter. The experiments of series $\mathrm{C}$ were conducted in four 5-litre perspex digesters. Digestion temperature was regulated by circulating thermostated water through a jacket. The digesters were thoroughly mixed by mechanical stirring at $100 \mathrm{rev} / \mathrm{min}$ for $15 \mathrm{~s}$ every $4 \mathrm{~min}$.

The fresh manure was added at the top of the digester whereas the effluent was discharged at the bottom. Also in these experiments the gas production was determined by means of a wet gas meter.

\section{Materials}

All digestion units were seeded with well digested sludge obtained from experimental digesters fed with $6 \%$ TS piggery manure and operated at $30{ }^{\circ} \mathrm{C}$. The VFA concentration of the seed material was less than $200 \mathrm{mg}^{-1}$. The three series

Table 1. Experimental scheme.

\begin{tabular}{llcl}
\hline & \multicolumn{2}{l}{ Series of experiments } & \\
\cline { 2 - 4 } & A & B & C \\
Load (kg TS m ${ }^{-3}$ day -1$)$ & & & \\
Detention time (days) & 3.3 & 4.2 & 3.6 \\
Temperatures investigated $\left({ }^{\circ} \mathrm{C}\right)$ & 22.5 & 15 & 20 \\
& 20 & 27 & 13 \\
\end{tabular}


Table 2. Manure characteristics.

\begin{tabular}{lccc}
\hline & Exp. A & Exp. B & Exp. C \\
TS (g/litre) & 74.0 & 63.3 & 71.6 \\
VS (g/litre) & 56.2 & 42.5 & 55.1 \\
COD supernatant (mg/litre) & 22770 & 17490 & 16020 \\
COD total (mg/litre) & 67500 & 64350 & 65000 \\
COD of the VFA (mg/litre) & 15890 & 9625 & 10243 \\
VFA (meq/litre) & 176.2 & 107.2 & 115 \\
Ammonia-nitrogen (as mg N/litre) & 2320 & 1840 & 1730 \\
Total nitrogen (as mg N/litre) & 3850 & - & 3810 \\
pH & 7.1 & 7.2 & 6.9 \\
\hline
\end{tabular}

of experiments were not conducted simultaneously so that the manure used in the various series differed with respect to origin and composition. The manure characteristics are summarized in Table 2.

The manure used in series $A$ originated from an experimental pig housing unit. The pigs were fed here ad libitum so that the manure may contain some spilled feed rests. The series $B$ experiments were conducted with manure from a pigfattening farm and those of series $\mathrm{C}$ with manure from an experimental farm where the manure solids and the manure liquid were discharged separately. Both fractions were combined in appropiate proportions before supplying it to the digester. The manure in this case partly consisted of saw dust and other litter material.

\section{Results}

The experimental results of series $\mathrm{A}, \mathrm{B}$ and $\mathrm{C}$ are shown in Tables 3,4 and 5 respectively. The data presented in these tables concern the average values of the

Table 3. Experimental results of series A (detention time 20 days; load $3.3 \mathrm{~kg} \mathrm{TS} \mathrm{m}^{-3}$ day-1).

\begin{tabular}{lccc}
\hline & Exp. $\mathrm{A}_{1}$ & Exp. $\mathrm{A}_{2}$ & Exp. $\mathrm{A}_{3}$ \\
Duration of experiment (days) & 95 & 95 & 95 \\
Temperature $\left({ }^{\circ} \mathrm{C}\right)$ & 20 & 25 & 30 \\
Gas production $\left(\mathrm{m}^{3} / \mathrm{kg} \mathrm{TS}\right)$ & 0.242 & 0.351 & 0.379 \\
Gas composition (\% methane) & 71.1 & 70.1 & 69 \\
Methane production (m $\mathrm{CH}^{3} / \mathrm{kg}$ TS) & 0.172 & 0.246 & 0.262 \\
$\quad\left(\mathrm{~m}^{3} \mathrm{CH}_{4} / \mathrm{kg}\right.$ VS) & 0.226 & 0.324 & 0.345 \\
& & & \\
pH & 7.4 & 7.55 & 7.6 \\
VFA concentration (meq/litre) & 18.9 & 3.2 & 2.7 \\
Acetic acid concentration (meq/litre) & 14.7 & 3.2 & 2.6 \\
Propionic acid concentration (meq/litre) & 3.8 & 0 & 0.1 \\
COD of the VFA (mg/litre) & 1429 & 205 & 171 \\
COD supernatant (mg/litre) & 7020 & 7220 & 5180 \\
Ammonia-nitrogen (as mg N/litre) & 2870 & 2990 & 2990 \\
Total nitrogen (as mg N/litre) & 3950 & 3680 & 3650 \\
\hline
\end{tabular}


Table 4. Experimental results of series B (detention time 15 days; load $4.2 \mathrm{~kg} \mathrm{TS} \mathrm{m}^{-3}$ day-1).

\begin{tabular}{|c|c|c|c|}
\hline & Exp. $B_{1}$ & Exp. B $_{2}$ & Exp. $\mathbf{B}_{3}$ \\
\hline Duration of experiments (days) & 90 & 90 & 90 \\
\hline Temperature $\left({ }^{\circ} \mathrm{C}\right)$ & 27 & 32 & 40 \\
\hline Gas production $\left(\mathrm{m}^{3} / \mathrm{kg} \mathrm{TS}\right)$ & 0.234 & 0.255 & 0.268 \\
\hline Gas composition (\% methane) & 74.0 & 72.8 & 73.5 \\
\hline \multirow{2}{*}{$\begin{array}{r}\text { Methane production }\left(\mathrm{m}^{3} \mathrm{CH}_{4} / \mathrm{kg} \text { TS }\right) \\
\qquad\left(\mathrm{m}^{3} \mathrm{CH}_{4} / \mathrm{kg} \text { VS) }\right.\end{array}$} & 0.173 & 0.186 & 0.197 \\
\hline & 0.258 & 0.277 & 0.293 \\
\hline pH & 7.6 & 7.65 & 7.7 \\
\hline VFA concentration (meq/litre) & 3.4 & 1.1 & 6.5 \\
\hline Acetic acid concentration (meq/litre) & 3.1 & 1.1 & 4.8 \\
\hline Propionic acid concentration (meq/litre) & 0.3 & 0 & 1.5 \\
\hline COD of the VFA (mg/litre) & 231 & 71 & 502 \\
\hline COD supernatant (mg/litre) & 7230 & 5760 & 7930 \\
\hline Ammonia-nitrogen (as mg N/litre) & 2330 & 2255 & 2273 \\
\hline Tota1 nitrogen (as $\mathrm{mg} \mathrm{N} /$ litre) & - & - & - \\
\hline
\end{tabular}

results during the last 25 days of the experiments when the digestion process had reached a steady state. In Tables 3 and 4 the values of TS, VS and total COD are not presented as they are inadequate due to the incomplete mixing of the digester contents in these series.

The gas production obtained in the reference approx. $30{ }^{\circ} \mathrm{C}$ experiments of each

Table 5. Experimental results of series $\mathrm{C}$ (detention time 20 days; load $3.6 \mathrm{~kg} \mathrm{TS} \mathrm{m}^{-3} \mathrm{day}^{-1}$ ).

\begin{tabular}{|c|c|c|c|c|}
\hline & Exp. $C_{1}$ & Exp. $C_{2}$ & Exp. $C_{3}$ & (in duplicate) \\
\hline Duration of experiment (days) & 73 & 73 & 80 & 80 \\
\hline Temperature $\left({ }^{\circ} \mathrm{C}\right)$ & 13 & 35 & 55 & 55 \\
\hline Gas production $\left(\mathrm{m}^{3} / \mathrm{kg} \mathrm{TS}\right)$ & 0 & 0.384 & 0.315 & 0.332 \\
\hline Gas composition (\% methane) & - & 65.0 & 58.5 & 59.0 \\
\hline \multirow{2}{*}{$\begin{array}{r}\text { Methane production }\left(\mathrm{m}^{3} \mathrm{CH}_{4} / \mathrm{kg} \text { TS }\right) \\
\qquad\left(\mathrm{m}^{3} \mathrm{CH}_{4} / \mathrm{kg} \text { VS) }\right.\end{array}$} & 0 & 0.249 & 0.184 & 0.196 \\
\hline & 0 & 0.324 & 0.239 & 0.25 \\
\hline $\mathrm{pH}$ & 6.7 & 7.4 & 7.8 & 7.7 \\
\hline TS (g/litre) & 72.6 & 52.4 & 57.1 & 55.8 \\
\hline VS (g/litre) & 56.3 & 36.1 & 40.0 & 39.4 \\
\hline VFA concentration (meq/litre) & 181.7 & 1.6 & 84.5 & 81.0 \\
\hline Acetic acid concentration (meq/litre) & 113.1 & 1.5 & 19.7 & 18.9 \\
\hline Propionic acid concentration (meq/litre) & 38.1 & 0.1 & 41.6 & 36.4 \\
\hline COD of the VFA (mg/litre) & 16740 & 115 & 10240 & 10220 \\
\hline COD supernatant (mg/litre) & 20640 & 5630 & 18080 & 17160 \\
\hline COD total (mg/litre) & 60060 & 37700 & 50000 & 49000 \\
\hline Ammonia-nitrogen (as $\mathrm{mg} \mathrm{N} /$ litre) & 1820 & 2061 & $\rightarrow 2430$ & $\rightarrow 2400$ \\
\hline Total nitrogen (as $\mathrm{mg} \mathrm{N} /$ litre) & 3790 & 3643 & 3740 & 3450 \\
\hline
\end{tabular}

$\rightarrow$ increasing to.

Neth. J. agric. Sci. 27 (1979) 
series differed considerably from each other. This should be mainly attributed to the use of manure of different origin and composition. Therefore, but also because of the application of different loading rates in the three series (between 3.3

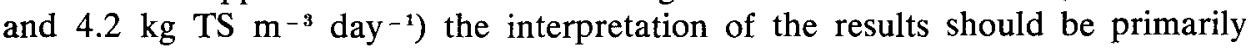
related to the data obtained within each separate series.

The results in Table 5 indicate that methane production is nihil at a process temperature of $13{ }^{\circ} \mathrm{C}$ under the conditions applied. This cannot be attributed to a lack of adequate substrate for the methane formers because of the high VFA concentration in the digester mixed liquor. The VFA concentration even increased from $115 \mathrm{meq} /$ litre in the manure feed to $181.7 \mathrm{meq} /$ litre in the $13{ }^{\circ} \mathrm{C}$ experiment.

However, at $20^{\circ} \mathrm{C}$ an active methane fermentation takes place (Table 3 ) which results in a sharp decrease in the VFA concentration of the digester contents with respect to fresh manure. The results presented in Table 3 also reveal that the activity of the bacterial sludge is considerably higher at $25^{\circ} \mathrm{C}$ (methane production $0.324 \mathrm{~m}^{3} / \mathrm{kg} \mathrm{VS}$ ) than at $20{ }^{\circ} \mathrm{C}$ (methane production $0.226 \mathrm{~m}^{3} / \mathrm{kg} \mathrm{VS}$ ). However, an increase of the temperature from 25 to $30^{\circ} \mathrm{C}$ does not further improve the methane production very significantly, viz only from $0.324 \mathrm{~m}^{3} / \mathrm{kg} \mathrm{VS}$ at $25^{\circ} \mathrm{C}$ to $0.345 \mathrm{~m}^{3} / \mathrm{kg}$ VS at $30^{\circ} \mathrm{C}$. Accordingly the results of series B (Table 4) show that the methane production increases only slightly and almost linearly with the digestion temperature in the range from 27 to $40{ }^{\circ} \mathrm{C}$. The results of the separate experiments within this series are very similar except that the VFA concentration and the COD of the supernatant solution in the $32{ }^{\circ} \mathrm{C}$ experiment are clearly lower than that in the $27^{\circ} \mathrm{C}$ and $40^{\circ} \mathrm{C}$ experiments.

The digestion at $55^{\circ} \mathrm{C}$ was investigated in two experiments, which showed very similar results (Table 5). A raise in temperature from 35 to $55{ }^{\circ} \mathrm{C}$ apparently adversely affects the gas production because the methane production at $55^{\circ} \mathrm{C}(0.243$ $\mathrm{m}^{3} / \mathrm{kg}$ VS $)$ is only $75 \%$ of that at $35^{\circ} \mathrm{C}\left(0.324 \mathrm{~m}^{3} / \mathrm{kg}\right.$ VS $)$. Furthermore the methane content of the gas produced under thermophilic conditions is somewhat lower.

In previous experiments (not published) extensive efforts were made to initiate thermophilic digestion at $55^{\circ} \mathrm{C}$ of piggery manure having an ammonia-nitrogen concentration of approx. $3000 \mathrm{mg} /$ litre. Under these circumstances methane production did not start. As it was believed that the main reason for the poor results of the latter experiments was the stronger inhibiting action of ammonia-nitrogen on the digestion process under thermophilic than under mesophilic conditions the following two experiments were carried out: (1) after finishing series $\mathrm{C}$ one of the $55{ }^{\circ} \mathrm{C}$ digesters was continously operated at $55^{\circ} \mathrm{C}$ and fed with $6 \%$ TS manure at a 30 days detention time (reference digester); (2) an other similar digestion unit was seeded with 5 litres of well digested piggery manure, acclimated at an ammonia-nitrogen concentration of $3000 \mathrm{mg} /$ litre at $30^{\circ} \mathrm{C}$. The second digester was operated similarly to the reference digester except that $5.1 \mathrm{~g}$ ureum/litre manure was added to increase the ammonia-nitrogen concentration in the digester contents to approx. $3800 \mathrm{mg} /$ litre.

The results of the additional thermophilic experiments presented in Table 6 indicate that at an ammonia-nitrogen concentration of $3800 \mathrm{mg} /$ litre gas produc- 


\section{A. F. M. VAN VELSEN, G. LETTINGA AND D. DEN OTTELANDER}

Table 6. Thermophilic digestion at different ammonia-nitrogen concentrations (temperature $55^{\circ} \mathrm{C}$; detention time 30 days; manure concentration $65 \mathrm{~g}$ TS; load $2.2 \mathrm{~kg} \mathrm{TS} \mathrm{m}^{-3}$ day-1).

\begin{tabular}{|c|c|c|c|}
\hline & Manure & Reference & Ureum added \\
\hline Duration of experiment (days) & & 50 & 50 \\
\hline Gas production $\left(\mathrm{m}^{3} / \mathrm{kg} \mathrm{TS}\right)$ & & 0.276 & 0.038 \\
\hline Gas composition (\% methane) & & 63 & 39 \\
\hline Methane production $\left(\mathrm{m}^{3} / \mathrm{kg}\right.$ TS $)$ & & 0.174 & 0.015 \\
\hline$\left(\mathrm{m}^{3} / \mathrm{kg} \mathrm{VS}\right)$ & & 0.235 & 0.021 \\
\hline $\mathrm{pH}$ & 7.2 & 7.9 & 7.7 \\
\hline COD of the VFA (mg/litre) & 3870 & 5380 & 12900 \\
\hline Acetic acid concentration (meq/litre) & 33.6 & 22.8 & 133 \\
\hline Propionic acid concentration (meq/litre) & 7.6 & 16.2 & 17.5 \\
\hline VFA concentration (meq/litre) & 46.6 & 50.3 & 164.4 \\
\hline COD of the supernatant ( $\mathrm{mg} /$ litre) & 8000 & - & - \\
\hline Ammonia-nitrogen ( $\mathrm{mg}$ as $\mathrm{N} /$ /itre) & 1200 & 1500 & 3800 \\
\hline
\end{tabular}

tion ceases almost completely and does not recuperate in the experimental period of 50 days whereas the methane production in the reference digester is very similar to that obtained in the $55^{\circ} \mathrm{C}$ experiments of series $\mathrm{C}$.

\section{Discussion}

The most obvious digestion characteristic for evaluating the influence of the temperature is the methane production, especially when energy recovery is the main objective for applying the digestion process. However, the methane production only represents the final degree of conversion and does not reveal the step in the process which is rate-limiting. To gain a better insight in the course of the digestion process which is necessary to optimize the process, the degree of conversion as obtained in three separate steps (hydrolysis, acid formation and methane formation) has been calculated.

In this calculation it is assumed that (1) in the hydrolysis step only undissolved organic matter is converted into dissolved fragments, (2) that VFA, hydrogen and carbon dioxide are exclusively formed by the acid-forming organisms and (3) that all methane originates from the end-products of the acid formation.

The degree of hydrolysis, acid formation and methane formation at the end of

Table 7. Influence of temperature on the degree of hydrolysis, acid formaton and methane formation (in \% of the manure COD).

\begin{tabular}{lcccc}
\hline & Manure & $13^{\circ} \mathrm{C}$ & $35^{\circ} \mathrm{C}$ & $55^{\circ} \mathrm{C}$ \\
Hydrolysis & 24.6 & 31.8 & 76.1 & 78.5 \\
Acid formation & 15.8 & 25.7 & 67.7 & 67.2 \\
Methane formation & 0 & 0 & 67.5 & 51.5 \\
\hline
\end{tabular}


the experiments (steady state) can now be calculated by the following equations (van Velsen, 1977):

hydrolysis $(\%) \quad=100(\mathrm{G}+\mathrm{S}) / \mathrm{M}$

acid formation $(\%) \quad=100(\mathrm{G}+\mathrm{V}) / \mathrm{M}$

methane formation $(\%)=100 \mathrm{G} / \mathrm{M}$

in which $\mathrm{G}=\mathrm{COD}$ removed via methane gas ( $\mathrm{g} / \mathrm{litre}$ )

$\mathrm{S}=\mathrm{COD}$ of the supernatant $(\mathrm{g} / \mathrm{litre})$

$\mathrm{M}=$ total manure $\mathrm{COD}$ ( $\mathrm{g} /$ litre)

$\mathrm{V}=\mathrm{COD}$ corresponding with the VFA concentration in the digester (g/litre).

The results of these calculations have been plotted versus the temperature in Fig. 1 for experimental series A en B and are presented in Table 7 for experimental series $\mathbf{C}$.

\section{Digestion at $13{ }^{\circ} \mathrm{C}$}

Literature data concerning the digestion of solid wastes such as sewage sludge indicate that methane production still takes place below $10^{\circ} \mathrm{C}$ though at a very slow rate. Contrary to these reports no gas is produced in the $13{ }^{\circ} \mathrm{C}$ experiment under the process conditions applied. The absence of methane production in this experiment may indicate that environmental factors such as the high ammonianitrogen concentration and the high $\mathrm{pH}$ levels in piggery manure together with the low temperature create conditions which are unfavourable for the methanogenic organisms.

Contrary to the results of experiments conducted in our laboratory indicating that methane-forming organisms accomodate well to changes in temperature between 10 and $45^{\circ} \mathrm{C}$ (Lettinga, 1979) the gas production in a piggery manure digester evidently ceases at a fall in temperature from 30 to $13{ }^{\circ} \mathrm{C}$.

Heukelekian et al. (1948) and Speece \& Kem (1970) also reported that at the digestion of sewage sludge the gas production did not continue immediately after a sudden decrease in temperature in this range.

The cessation of the methane production in combination with the application of a 20-day detention time immediately after the start of the experiments may have caused a wash-out of methanogenic bacteria. Therefore better results may be expected when more time is taken to acclimate the bacterial population to the change in temperature.

The results in Table 7 also indicate that hydrolysis is very incomplete. This may be attributed (1) to the low activity of the hydrolytic enzyme complexes at this temperature and/or (2) to an inhibition of the hydrolysis by the end-products of the acid formation, such as VFA and hydrogen, which accumulate in the digester contents.

Digestion at mesophilic temperatures $\left(20-40^{\circ} \mathrm{C}\right)$

As appears from Fig. 1 all three separate steps of the digestion process (hydrolysis, acid formation and methane formation) are affected to about the same extent by the temperature in the range of 20 to $40{ }^{\circ} \mathrm{C}$. Hence it can be concluded that changes 


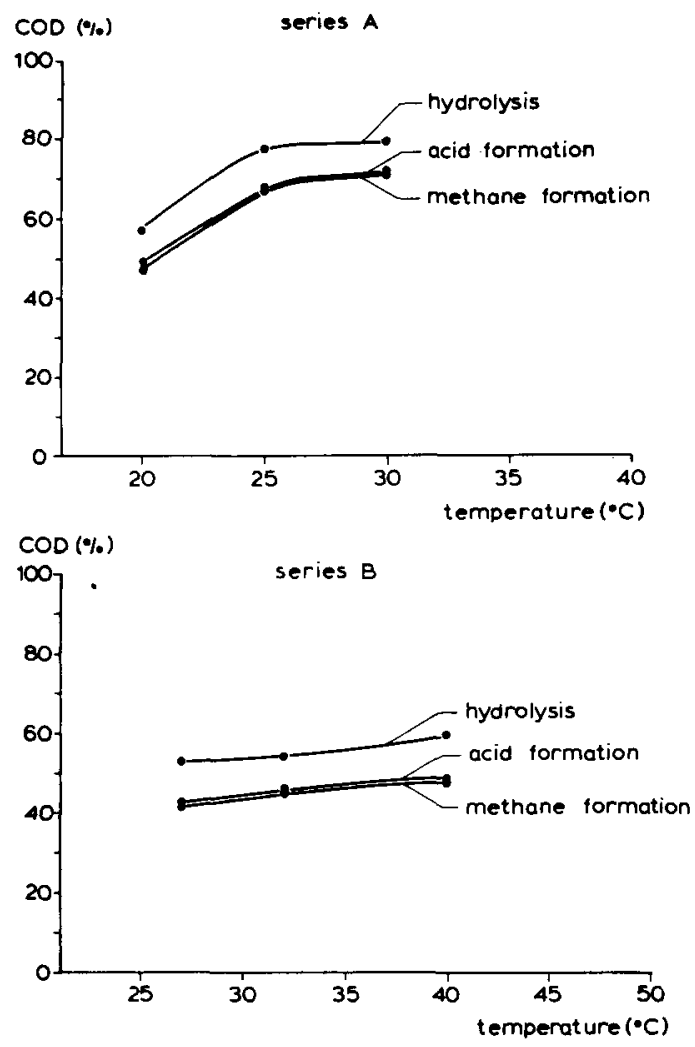

Fig. 1. Influence of temperature in the mesophilic range $\left(20\right.$ to $\left.40^{\circ} \mathrm{C}\right)$ on hydrolysis, acid formation and methane formation.

in the methane production at the different temperatures investigated should be attributed mainly to changes in the rate of hydrolysis. The fact that in the digestion of solid wastes hydrolysis frequently is the rate-limiting step was already observed by Pfeffer (1974), in investigating the effect of temperature on the digestion of domestic refuse and by van Velsen (1977) in digestion experiments with piggery manure at different loading rates at $30^{\circ} \mathrm{C}$. Evidently the methane production in the underlying experiments reflects in fact the influence of temperature on the rate of hydrolysis.

Fig. 1 reveals that the rate of hydrolysis strongly increases when the temperature is raised from $20{ }^{\circ} \mathrm{C}$ to $25^{\circ} \mathrm{C}$. The combined results of series $\mathrm{A}$ and $\mathrm{B}$ indicate that the rate of hydrolysis - and therefore the gas production - increases almost linearly with the temperature in the range of 25 to $40^{\circ} \mathrm{C}$. The average rate of increase in gas production amounts to approx. $1 \%$ per ${ }^{\circ} \mathrm{C}$.

Correspondingly Fair \& Moore (1934), in summarizing the results of batch experiments concerning the influence of temperature on the digestion of sewage solids, concluded that it was possible to approximate the relation between the relative rate of digestion and the temperature in the range of 25 to $40^{\circ} \mathrm{C}$ by a straight line and that only little could be gained by raising the digestion tempera- 
ture above $25^{\circ} \mathrm{C}$. Also Golueke (1958) reported a linear relationship between temperature $\left(30-40^{\circ} \mathrm{C}\right)$ and gas production at the digestion of raw sewage sludge at a load of $1.45 \mathrm{~kg} \mathrm{VS} \mathrm{m}^{-3}$ day $^{-1}$.

In establishing the effect of the temperature on the digestion an important factor to be considered should be the detention time. At a shorter, and therefore more critical, detention time the differences in methane production at different temperatures presumably are more significant. Hobson et al. (in press) conducted experiments with pig slurry at a 10-day detention time and reported an increase in the gas production from $0.30 \mathrm{~m}^{3} / \mathrm{kg}$ TS at $30^{\circ} \mathrm{C}$ to $0.42 \mathrm{~m}^{3} / \mathrm{kg}$ TS at $40^{\circ} \mathrm{C}$ which corresponds to an average increase in the gas production of $4 \%$ per ${ }^{\circ} \mathrm{C}$.

\section{Digestion at $55^{\circ} \mathrm{C}$}

The increase of the digestion temperature from 35 to $55^{\circ} \mathrm{C}$ resulted in a decrease in the gas production of approx. $25 \%$ in spite of a slight increase in the degree of hydrolysis (Table 7), which has to be attributed to an improved conversion of carbohydrates and nitrogenous substances such as proteins.

Table 8 , which contains a rough estimate of the relative breakdown of carbohydrates at digestion temperatures of 13,35 and $55^{\circ} \mathrm{C}$, indicates that the conversion of both cellulose and hemicellulose increases at increasing temperatures. The breakdown of nitrogenous components can be more or less followed by the ammonia-nitrogen concentration before and after digestion. These analyses give only an impression of the overall process because apart from the release of ammonianitrogen during the breakdown of nitrogenous substances, part of the ammonianitrogen is incorporated in new cell material. Furthermore some ammonia-nitrogen may be lost from the digestion liquor with the gas. The ammonia-nitrogen concentration in the experimental series $\mathrm{C}$ increased significantly with increasing temperature, i.e. from $1820 \mathrm{mg} /$ litre at $13{ }^{\circ} \mathrm{C}$ to $2400 \mathrm{mg} /$ litre at $55^{\circ} \mathrm{C}$, which points to an increased conversion of nitrogenous components at $55^{\circ} \mathrm{C}$.

The both higher VFA concentration and supernatant COD at thermophilic as compared to mesophilic digestion has also been observed by Buhr et al. (1977), Golueke (1958), Garber et al. (1975), Pohland \& Bloodgood (1963). Apparently the observed decrease in the gas production in the underlying experiments is due to both a less complete acid and methane formation.

Earlier investigations on the effect of temperature on anaerobic digestion of wastes gave rather conflicting results. Heukelekian (1930) and Fair \& Moore (1932) found in batch experiments with sewage sludge both a higher gas production

Table 8. Rough estimate of the reduction of hemicellulose and cellulose as observed in digestion experiments with wet piggery manure at different temperatures (in $\%$ of the manure concentration). Lignine is used as an internal standard.

\begin{tabular}{llll}
\hline & $13{ }^{\circ} \mathrm{C}$ & $35^{\circ} \mathrm{C}$ & $55^{\circ} \mathrm{C}$ \\
Hemicellulose & 38 & 43 & 53 \\
Cellulose & 34 & 39 & 52 \\
\hline
\end{tabular}


and gas production rate at increasing temperatures up to $60^{\circ} \mathrm{C}$, whereas Maly \& Fadrus (1971) found in similar experiments that this only holds for the gas production rate. Continuous experiments at different temperatures were conducted with municipal sewage sludge (Golueke, 1958; Pohland et al., 1963; Malina, 1961; Garber et al., 1975) and shredded domestic refuse (Pfeffer, 1974). Garber et al. (1975) and Pfeffer (1974) reported an increase in the gas production with increasing the temperature from the mesophilic to the thermophilic range. On the other hand the reports of Golueke (1958), Pohland \& Bloodgood (1963) and Malina (1961) showed a similar or somewhat lower gas production at thermophilic as compared with mesophilic temperatures. These discrepancies in the reports may be caused either by differences in the acclimation procedures followed or by the influence of some yet unidentified inhibitory agent for thermophilic methanogenic organisms.

Anyhow, the results obtained in the additional experiment conducted in the present study where the ammonia-nitrogen concentration was increased from 1500 $\mathrm{mg} /$ litre to $3800 \mathrm{mg} /$ litre, clearly show that ammonia-nitrogen severely inhibits the methane formation under thermophilic conditions. In fact such an inhibition also occurs under mesophilic conditions but recent results (van Velsen, 1979a) have shown that the digestion process can acclimate in that case to ammonianitrogen concentrations up to $3500 \mathrm{mg} /$ litre as applied in the present experiment. Apparently this does not occur in the $55^{\circ} \mathrm{C}$ experiment.

The increasing inhibitory effect of ammonia-nitrogen on the digestion process with increasing temperature is presumed to be caused by an increase in the fraction of undissociated ammonia at increasing temperature (at constant $\mathrm{pH}$ and total ammoniacal nitrogen concentration).

The fraction of free ammonia under a given set of conditions can be calculated by Eq. 1 .

$$
\mathrm{NH}_{3}-\mathrm{N}=\mathrm{NH}_{4}+-\mathrm{N} \frac{10^{p H}}{\mathrm{k}_{\mathrm{b}} / \mathrm{k}_{\mathrm{w}}+10 \mathrm{p}^{\mathrm{H}}}
$$

in which

$\mathrm{NH}_{3}-\mathrm{N}=$ concentration of undissociated ammonia-nitrogen (mg/litre)

$\mathrm{NH}_{4}{ }^{+}-\mathrm{N}=$ concentration of total ammoniacal nitrogen $(\mathrm{mg} /$ litre $)$

$\mathbf{k}_{\mathrm{b}} \quad=$ dissociation constant of aqueous ammonia

$\mathrm{k}_{\mathrm{w}} \quad=$ ionization constant for water.

For a total ammoniacal nitrogen concentration of $3500 \mathrm{mg} /$ litre a calculation shows that at $\mathrm{pH}=8$ the free ammonia-nitrogen is $970 \mathrm{mg} /$ litre at $55^{\circ} \mathrm{C}\left(\mathrm{k}_{\mathrm{h}}=\right.$ approx. $1.905 \times 10^{-5}$ (Weast, 1964)) and only $260 \mathrm{mg} /$ litre at $30^{\circ} \mathrm{C}\left(\mathrm{k}_{\mathrm{b}}=1.820 \times 10^{- \text {s }}\right.$ (Weast, 1964))!

As it is presumed (McCarthy et al., 1961) that undissociated ammonia-nitrogen is the inhibiting agent for the methane-formation, it is clear that the effect of ammonia-nitrogen should be considerably greater under thermophilic than under mesophilic conditions. 


\section{Determination of the optimum digestion temperature}

The experimental results reveal that the mesophilic temperature range is most adequate for the digestion of wet piggery manure. At a submaximum load of 4.0 $\mathrm{kg}$ TS $\mathrm{m}^{-3}$ day $^{-1}$, which is imperative when the abatement of odour nuisance is focussed (van Velsen, 1979b), the gas production increases almost linearly in the temperature range from 25 to $40{ }^{\circ} \mathrm{C}$.

Starting from the results of experimental series $\mathrm{B}$ a raise in temperature from 27 to $40{ }^{\circ} \mathrm{C}$ causes an increase in the methane production from $0.024 \mathrm{~m}^{3} / \mathrm{kg}$ TS (Table 4) which corresponds to a heating value of $0.865 \mathrm{MJ} / \mathrm{kg}$ TS. On the other hand the heating of $6 \%$ TS manure from 27 to $40{ }^{\circ} \mathrm{C}$ theoretically demands 0.91 $\mathrm{MJ} / \mathrm{kg} \mathrm{TS}$, indicating that, apart from higher radiant losses at $40^{\circ} \mathrm{C}$, the extra methane production is not sufficient to heat the manure from 27 to $40{ }^{\circ} \mathrm{C}$, even not at a $100 \%$ efficiency of the energy conversion.

The energy balance might be more positive when more concentrated manure is digested. However, the gas production per $\mathrm{kg}$ TS decreases at increasing manure concentrations above $6 \%$ TS (van Velsen, 1977). Therefore, when the heat requirements of a digester have to be supplied exclusively with high-grade fuel, for example part of the methane produced, the optimum temperature with respect to the net energy recovery is at the lower part of the mesophilic range, i.e. between 27 and $30^{\circ} \mathrm{C}$. On the other hand when sufficient waste energy, for example cooling water of a gas motor/generator set, is available the optimum process temperature for energy recovery may be at the upper part of the mesophilic range, i.e. $40{ }^{\circ} \mathrm{C}$, when the maximum gas production is obtained.

\section{Conclusions}

- Digestion under mesophilic conditions is most adequate for piggery waste stabilization. At a load of approx. $4 \mathrm{~kg} \mathrm{TS} \mathrm{m}^{-3}$ day ${ }^{-1}$ gas production increases almost linearly with temperature in the range of 25 to $40^{\circ} \mathrm{C}$. At these temperatures hydrolysis is the rate limiting step in the process.

- The optimum temperature with respect to the net energy recovery is approx. $27-30^{\circ} \mathrm{C}$ in case high grade fuel is required to elevate the temperature. However, when sufficient waste energy is available the optimum digestion temperature may be approx. $40{ }^{\circ} \mathrm{C}$.

- A continuous digestion of piggery waste at a temperature of $13{ }^{\circ} \mathrm{C}$ is unsuccess$\mathrm{ful}$, because the methane production is nihil under these conditions.

- Thermophilic digestion of manure at an ammonia-nitrogen concentration in the range of 1700 to $2400 \mathrm{mg}$ /litre results in a slightly increasing hydrolysis and in a significantly decreasing methane production, i.e. by approx. $25 \%$ as compared to mesophilic digestion. At increased ammonia-nitrogen concentrations $(3800 \mathrm{mg} /$ litre) the gas production at $55^{\circ} \mathrm{C}$ ceases almost completely, presumably due to the occurrence of increasing concentrations of free ammonia at increasing temperatures. 


\section{A. F. M. VAN VELSEN, G. LETTINGA AND D. DEN OTTELANDER}

\section{References}

American Public Health Association, 1965. Standard methods of water and sewage analysis, 12 th edition.

Buhr, H. O. \& J. F. Andrews, 1977. The thermophilic anaerobic digestion process. Water Res. 11 (2) 129-143.

Fair, G. M. \& E. W. Moore, 1932. Heat and energy relations in the digestion of sewage solids III. Sewage Works J. 4 (4) 589-600.

Garber, W. F., G. T. Ohara, J. E. Colbaugh \& S. K. Raksit, 1975. Thermophilic digestion at the Hyperion Treatment Plant. J. Water Poll. Control Fedn 47 (5) 950-961.

Golueke, C. G., 1958. Temperature effects on anaerobic digestion of raw sewage sludge. Sewage ind. Wastes 30 (10) 1225-1232.

Heukelekian, H., 1930. Further studies on thermophilic digestion of sewage solids. Sewage Works J. 2 (2) 219-227.

Heukelekian, H. \& A. J. Kaplovsky, 1948. Effect of change of temperature on thermophilic digestion. Sewage Works J. 20 (5) 806-816.

Hobson, P. N., S. Bousfield, R. Summers \& P. J. Mills (in press). Anaerobic digestion of farm animal wastes. Paper presented at the E.E.C. seminar 'Engineering problems with effluents from livestock' (Cambridge, England, 1978).

Lettinga, G., 1979. Direct anaerobic treatment handles wastes effectively. Ind. Wastes 25 (1) 18 .

Malina, J. F. Jr., 1961. The effect of temperature on high-rate digestion of activated sludge. Proc. 16th ind. Waste Conf. (Purdue Univ.): 232-251.

Maly, J. \& H. Fadrus, 1971. Influence of temperature on anaerobic digestion. J. Water Poll. Control Fedn 43 (4) 641-650.

McCarty, P. L. and R. E. McKinney, 1961. Salt toxicity in anaerobic digestion. J. Water Poll. Control Fedn 33 (4) 399.

Mills, P. J., 1979. Minimisation of energy input requirements of an anaerobic digester. Agric. Wastes 1 (1) 57-66.

Pfeffer, J. T., 1974. Temperature effects on anaerobic fermentation of domestic refuse. Biotechnol. Bioengng 16: 771-787.

Pohland, F. G. \& D. E. Bloodgood, 1963. Laboratory studies on mesophilic and thermophilic anaerobic sludge digestion. J. Water Poll. Control Fedn 35 (1) 11-42.

Speece, R. E. \& J. A. Kem, 1970. The effect of short-term temperature variations on methane production. J. Water Poll. Control Fedn 42 (11) 1990-1997.

Velsen, A. F. M. van, 1977. Anaerobic digestion of piggery waste I. The influence of detention time and manure concentration. Neth. J. agric. Sci. 25: 151-169.

Velsen, A. F. M. van, 1979a. Adaptation of methanogenic sludge to high ammonia-nitrogen concentrations. Water Res. 13: 995-999.

Velsen, A. F. M. van, 1979b. Anaerobic digestion of piggery waste II. Start-up procedure. Neth. J. agric. Sci. 27: 142-152.

Weast, R. C. (Ed.), 1972-73. Handbook of chemistry and physics, 45th ed. CRC Press, West Palm Beach, Florida. 